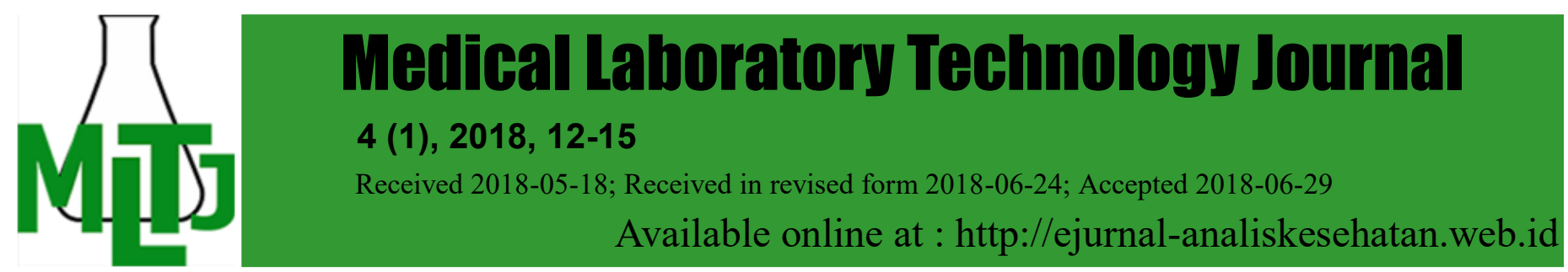

\title{
EFFECT OF ACTIVE CARBON OF COFFEE ROBUSTA WASTE (Coffea Ro- busta Lindl.) IN REDUCING IRON OF PEAT WATER
}

\author{
Dinna Rakhmina, Rizki Mulanova, Haitami \\ Department of Medical Laboratory Technology Poltekkes Kemenkes Banjarmasin \\ Mistar Cokrokusumo Street 4a Banjarbaru, Indonesia. \\ e-mail: dinnapoltekesbjm@gmail.com
}

\begin{abstract}
Peat water has a distinctive dark brown or yellow color, low $\mathrm{pH}$, it tastes sour, high organic matter content, high levels of iron and manganese. One of the ways that can be used to reduce the levels of iron in peat water is doing adsorption process by using activated carbon coffee waste because the coffee waste included organic ingredients. The purpose of this research was to identify the influence of the concentration of activated carbon robusta coffee waste (Coffea robusta Lindl.) against the iron levels in peat water. This research uses the draft Posttest-Only Control Group Design. Manufacture of activated carbon robusta coffee waste (Coffea robusta Lindl.) consists of the processes of dehydration, carbonization, and activation, with the results $25.9 \%$ of rendemen, $14.05 \%$ water content, a rate of $9.9 \%$ ash, and iod absorbance $647.19 \mathrm{mg} / \mathrm{g}$. Activated carbon coffee waste added to $100 \mathrm{ml}$ of peat water as much as 3 $\mathrm{gr}, 4.5 \mathrm{gr}$, and $6 \mathrm{gr}$ with the stirring speed $400 \mathrm{rpm}$ for 60 minutes obtained early iron levels of $2.75 \mathrm{mg} / \mathrm{L}$ and dropped to $1.19 \mathrm{mg} / \mathrm{L}, 1.02 \mathrm{mg} / \mathrm{L}$, and $0.95 \mathrm{mg} / \mathrm{L}$. Conclusions This study is there is the influence of the concentration of activated carbon robusta coffee waste (Coffea robusta Lindl.) against the iron level of peat water iron and frequency of $6 \mathrm{gr}$ as a concentration of the best efficiency adsorption of $65.4 \%$ because it can reduce the levels of iron in $100 \mathrm{ml}$ of peat water from $2.75 \mathrm{mg} / \mathrm{L}$ be $0.95 \mathrm{mg} / \mathrm{L}$. By regulation of the Minister of health RI No. 416/ Menkes/PER/IX/1990 namely of $1.0 \mathrm{mg} / \mathrm{L}$. Suggestions for further research to improve the heating temperature and concentration of the activator to obtain active carbon absorption .
\end{abstract}

Keywords: activated carbon; coffee waste; peat water; iron levels

\section{INTRODUCTION}

Indonesia has an extensive peatland which is about 20.6 million hectares or $10.8 \%$ of Indonesia's land area, mostly in Sulawesi $3 \%$, Papua 30\%, Kalimantan 32\% and Sumatra $35 \%$. Peat swampland is a swampland dominated by peat soil. Peat soil is a watersaturated soil, composed of organic soil material in the form of plant residue and plant tissue that has decomposed with a thickness of more than $50 \mathrm{~cm}$ (Suriadikarta, 2008; Mubeksti, 2011; Herman, 2016).

The water contained in peat soil characterized by high color intensity (yellow or dark brown), low pH between 3-4, acid taste, high organic matter content, iron content $(\mathrm{Fe})$ and manganese $(\mathrm{Mn})$ is high. Not only that, residents who live in peatlands are getting harder to get clean water when the dry season arrives because the taste of the water becomes salty
(Suriadikarta, 2005; Pahlevi, 2009).

One of the areas in South Kalimantan that has peatlands is Gambut Sub-district, Banjar district. Some citizen in Gambut subdistrict still uses well water and river water because they have not received clean water service from PDAM. Therefore, a preliminary test was conducted using two samples of peat water on Handil Durian street and A. Yani street $\mathrm{Km}$. 14.7 so that the value of the iron content of $3.67-5.25 \mathrm{mg} / \mathrm{L}$. These results suggest that the dissolved iron content in peat water in Gambut sub-district exceeds the maximum limit outlined in Regulation of the Minister of Health No. RI. 416/Menkes/PER/IX/1990 which amounted to $1.0 \mathrm{mg} / \mathrm{L}$.

Excess iron content $(\mathrm{Fe})$ is very harmful to the body. Excess Iron (Fe) can cause poisoning, with symptoms of vomiting, diarrhea and intestinal damage. 
Therefore, to be used for daily activities, weight of the coffee waste before carbonizathere must be a way to reduce the iron (Fe) tion and the weight after carbonization. Meascontent contained in peat water. One of the urement the moisture content is carried out by ideas that can be used to overcome this prob- weighing 1 gram of activated carbon inserted lem is by the adsorption process using activat- into a weighed porcelain cup and known by ed carbon because it considered more effec- weight. Porcelain cup containing activated cartive, comfortable, and financing is relatively bons was introduced into the oven at $105^{\circ} \mathrm{C}$ for cheap compared with other methods (Huda et 3 hours, cooled in a desiccator and weighed in al., 2015).

Many materials that can make into actimass. Measurement The ash content is carried out by holding one gram of activated carvated carbon one of which is the coffee bon inserted into a weighted and weighted grounds. According to Sugiharto in Irmanto porcelain plate, permitted in a furnace at $400^{\circ}$ and Suyata (2009), coffee grounds include or- C for 2 hours or until all becomes ash, cooled ganic materials that can make into activated in a desiccator and weighed in mass.

carbon for use as adsorbents or absorbent materials. Coffee waste is usually more discarded because it is considered waste, but actually, coffee grounds can utilize as activated carbon that will add value function as an adsorbent to increase the carrying capacity to the environment, especially in the climate of peat swamp land. This study aims to determine the usefulness of activated carbon from coffee grounds as an adsorbent in lowering iron (Fe) in peat water.

\section{MATERIALS AND METHODS}

The research was true-experiment with posttest only control group design (Notoadmodjo, 2010). The controls were performed using peatless water samples $(0 \mathrm{~g})$. Posttest completed by the addition of activated carbon of robusta coffee pulp (Coffea robusta Lindl.) weighing 3 grams; $4.5 \mathrm{gr} ; 6$ grams in $100 \mathrm{ml}$ of peat water sample. Measurement of peat iron water level using UV-Vis Spectrophotometer method after the addition of activated carbon of robusta coffee pulp (Coffea robusta Lindl.).

The activation of activated carbon coffee grounds by robusta coffee pulp (Coffea robusta Lindl.) dried in the sun for one day. 210 gram of coffee spilled in the furnace at $450^{\circ} \mathrm{C}$ for 45 minutes. After the drying process is complete, the coffee grounds are sieved with a mesh size of 100 mesh then allowed to cool and stored in a desiccator. Activated carbon immersed in a $2 \mathrm{M} \mathrm{HCl}$ activating solution for 48 hours and then drained and washed with distillate water until neutral and then dried in the oven at $100^{\circ} \mathrm{C}$ for 4 hours to remove water content.

Test the absorption of activated carbon to iodine by weighing 0.5 grams of active carbon and moving it into a dark and closed place. Added $50 \mathrm{ml}$ of $0.1 \mathrm{~N}$ iodine solution then shaken for 15 minutes then filtered. The filtrate is piped $10 \mathrm{ml}$ into the Erlenmeyer and titrated with $0.1 \mathrm{~N}$ sodium thiosulfate solution. If the yellow color of the solution is almost gone, the starch indicator added, the titration is continued until the blue color disappears (Rizki et al., 2015; Huda et al., 2015).

The treatment of activated carbon dregs of coffee grounds in peat water by preparing $100 \mathrm{ml}$ of peat water into beaker glass, added activated carbon powder of coffee cake with 3 gr content; $4.5 \mathrm{gr} ; 6 \mathrm{gr}$ in each glass, stirring with Stuart Scientific orbital shaker at $400 \mathrm{rpm}$ for 1 hour, silenced for 2 hours, then filtered using filter paper, transferred to erlenmayer and 3 times iron measurements taken using UV-spectrophotometer Vis.

Examination of iron content in water with a $5.0 \mathrm{ml}$ memipet sample using clinipet then put into a test tube. Added 3 drops of $\mathrm{Fe}-1$ ragen with upright, allowed to stand perpendicularly for 3 minutes for reaction time until red violet is formed. Measured by UV-Vis spectrophotometer with a wavelength of $510 \mathrm{~nm}$.

\section{RESULT AND DISCUSSION \\ Active Carbon Quality Standards}

The results of character analysis of water content and ash content in activated carbon of robusta coffee pulp (Coffea robusta Lindl.) Fulfill SNI requirement but very close to maximum limit. In this research, the temperature of heating with oven $105^{\circ} \mathrm{C}$ for 3 hours was obtained by the water content of $14.05 \%$,

The measurement of rendemen of acti- close to the makismum limit of $15 \%$ (table 1 ). vated carbon calculated by comparing the 
In the process of carbonization the results obtained in the form of carbon that is still covered with gas, carbon tar and ash. To expand the pores of activated activated carbon, which in this study using $2 \mathrm{M} \mathrm{HCl}$ activator. The acti- 2 vator will seep into the activated carbon opening the previously closed surface, breaking the hydrocarbon bonds and separating the carbon from other compounds (Sinaga, 2014). The type and concentration of the activator can influence the activator's effectiveness in opening the pore of activated carbon and in this study the activation with $\mathrm{HCl} 2 \mathrm{M}$ still leaves $9.9 \%$ ash which is not separated from the maximum limit of $10 \%$.

The absorptive quality as well as the pore surface area can be known by lod absorption test. The greater the absorption value of lod the greater the adsorption power of the activated carbon. It also means that lod absorption is related to the heating temperature as well as the type and concentration of the activator. The results of this study indicate the absorption of iod of $647.19 \mathrm{mg} / \mathrm{g}$ is still below the minimum limit of $750 \mathrm{mg} / \mathrm{g}$.

Table 1. Results of Active Carbon Parameter Analysis

\begin{tabular}{lll}
\hline Parameter & SNI No. 06-3730- & \\
\hline Rendemen & 1995 & Analysis Results \\
\hline Moisture & - & $25.9 \%$ \\
Content & Max. $15 \%$ & $14.05 \%$ \\
Ash Content & Max. $10 \%$ & $9.9 \%$ \\
lod Absorption & Min. $750 \mathrm{mg} / \mathrm{g}$ & $647.19 \mathrm{mg} / \mathrm{g}$ \\
\hline
\end{tabular}

\section{Reduction in Iron Content}

In this study, the activated carbon with the absorption capacity of iod below the minimum SNI limit of $647.19 \mathrm{mg} / \mathrm{g}$, therefore, to increase the absorption of the effort can be done is to add the concentration of activated carbon, because the more active carbon used, the more pore which can absorb iron. With the absorption capacity of $647.19 \mathrm{mg} / \mathrm{g}$ used up to 6 grams of activated carbon to be able to reduce $2.75 \mathrm{mg} / \mathrm{L}$ iron content to $0.95 \mathrm{mg} / \mathrm{L}$ and has been by the Regulation of the Minister of Health RI. 416 / Menkes / PER / IX / 1990 which is the standard quality of dissolved iron in water of $1.0 \mathrm{mg} / \mathrm{L}$. While at concentrations of $3 \mathrm{gr}$ and $4.5 \mathrm{gr}$ only obtained the decrease of $1.19 \mathrm{mg} / \mathrm{L}$ and $1.02 \mathrm{mg} / \mathrm{L}$ (figure 1). The less carbon used in $100 \mathrm{ml}$ of water allows for more water to increase the value and value of activated carbon of robusta coffee pulp (Coffea robusta Lindl.).

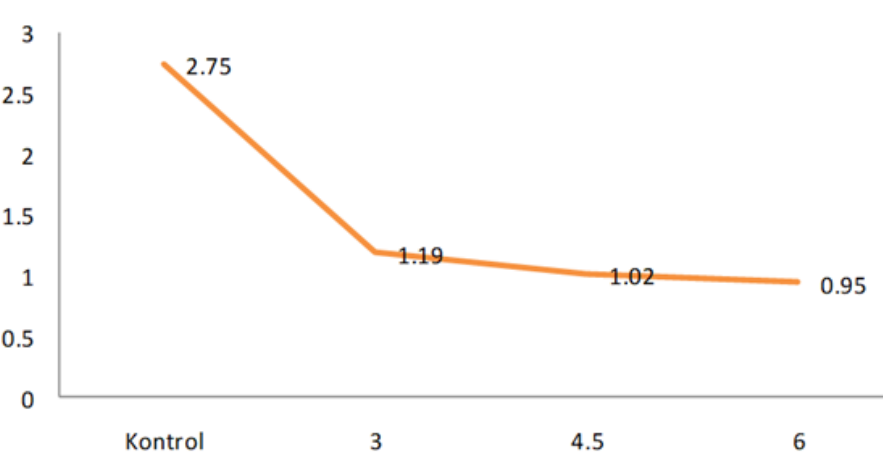

Figure 1. Effect of activated carbon from Robusta coffee pulp (Coffea robusta Lindl.) to decrease the iron content

The reduction in iron levels that have not been optimal with the addition of activated carbon may be influenced by several factors. In this study, controls of other compounds such as $\mathrm{Al}, \mathrm{Mn}, \mathrm{Zn}$, and $\mathrm{Cu}$ are not present in peat water so as to interfere with the absorption of activated carbon to iron, whereas activated carbon has a very active property to absorb chemicals, heavy metals, whether in the form of gas or liquid contact with it. In addition, in the adsorption process there are other factors that can not be controlled and very potential to disrupt the course of adsorption adsorption molecule size. The tug-of-war between molecules gets larger as the molecular size approaches the pore size of activated carbon. So it is likely that compounds with molecular size closer to the pore size of activated carbon adsorbed earlier than iron.

In this study, the concentration of $6 \mathrm{gr}$ is the best concentration of activated carbon of robusta coffee pulp (Coffea robusta Lindl.) To reduce the iron content in peat water, because the concentration of $6 \mathrm{gr}$ has the highest adsorption efficiency of $65,4 \%$ peat water from $2.75 \mathrm{mg} / \mathrm{L}$ to $0.95 \mathrm{mg} / \mathrm{L}$ (figure 2). The content is in accordance with the Regulation of the Minister of Health RI No. 416 / Menkes / PER / IX / 1990 which is the standard quality of dissolved iron in water of $1.0 \mathrm{mg} / \mathrm{L}$. 


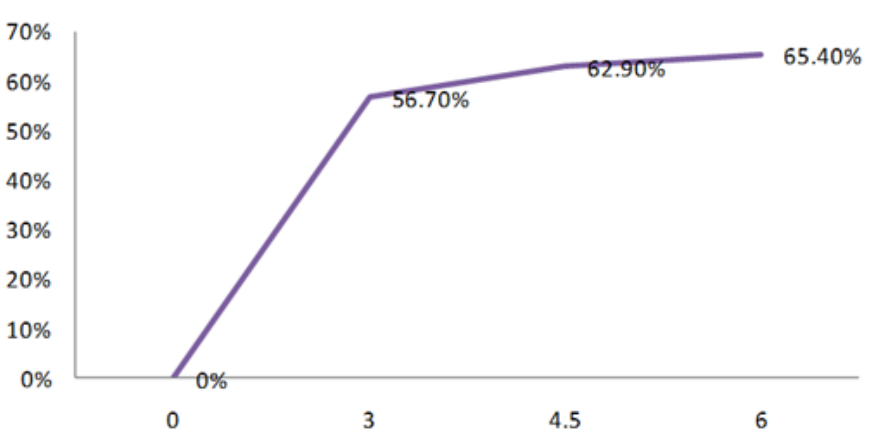

Figure 2. Percentage of Efficiency Improvement of Activated Carbon Concentration of Robusta Coffee Basin (Coffea robusta Lindl.) on Iron Content

Based on statistical test results using Friedman test followed by Wilcoxon test reading decrease iron content on $100 \mathrm{ml}$ of peat water with the addition of activated carbon of $3.0 \mathrm{gr} ; 4.5 \mathrm{gr}$; and $6.0 \mathrm{~g}$ showed a significant difference at each concentration where a significance value of 0,000 obtained which means less than $\alpha$, where $\alpha=0.05$. In the Linear Regression test the result of decreasing iron content in $100 \mathrm{ml}$ of peat water with the addition of activated carbon of $3.0 \mathrm{gr} ; 4.5 \mathrm{gr}$; and $6.0 \mathrm{gr}$ indicate that there is significant influence seen on significance value 0.000 $(<0.05)$ and regression equation $y=2.520-$ $0.309 x$ where $y=$ iron content and $x=$ active carbon concentration and $\mathrm{R} 2=0.660$. With this, $\mathrm{Ho}$ is rejected because $\mathrm{P}<\alpha$ which means there is an effect of the addition of activated carbon of robusta coffee pulp (Coffea robusta Lindl.) To the peat water level of peat water.

From the statistic test results, the activated carbon of Robusta coffee pulp (Coffea robusta Lindl.) Has a significant influence on the decrease of iron content that is equal to $65.4 \%$ ( $P$ value $<0.05$ ), so the result of this research is beneficial for society because it can be used with easy on peat water without special treatment of compounds other than iron and has a significant influence in lowering iron levels.

\section{CONCLUSION}

There is an effect of the addition of activated carbon of robusta coffee pulp (Coffea robusta Lindl.) To the reduction of the iron water level of peat water by $0.95 \mathrm{mg} / \mathrm{L}$ with $65.4 \%$ adsorption efficiency with 0.000 significance.

\section{REFERENCE}

Herman. (2016). Upaya Konservasi dan Rehabilitasi Lahan Gambut Melalui Pengembangan Lahan Basah Industri Perkebunan Sagu. In Prosisidng Seminar Nasional Lahan Basah (pp. 54-61).

Huda, H., Ardi, Z., Johansyah, A. A. (2015). Studi Kinetia, H., ka Adsorpsi Nilai Besi Pada Air Sumur Menggunakan Karbon Aktif Dari Ampas Kopi. Jurnal IPTEK, 19 (2), 49-58.

Irmanto, \& Suyata. (2009). Penurunan Kadar Amonia, Nitrit, dan Nitrat Limbah Cair Industri Tahu Menggunakan Arang Aktif Dari Ampas Kopi. Molekul, 4(2), 105-114.

Mubekti. (2011). Studi Pewilayahan Dalam Rangka Pengelolaan Lahan Gambut Berkelanjutan di Provinsi Riau, Jurnal Sains dan Teknologi Indonesia. Jurnal Sains Dan Teknologi Indonesia, 13(2), 88 -94 .

Notoatmodjo, S. (2010). Metodologi Penelitian Kesehatan. Jakarta: PT. Rineka Cipta.

Pahlevi, M. R. (2009). Analisis Kadar Besi (Fe) dan Mangan (Mn) dari Air Gambut Setelah Dijernihkan dengan Penambahan Tulang Ayam. Universitas Sumatera Utara, Medan.

Rizki, A. P., Sanjaya, A. S. (2015). Cinetics Study of $\mathrm{Fe}$ Content Decrease In Well Water With Activated Carbon Adsorption Of Coffe Waste. In Prosiding Seminar Nasional Teknik Kimia "Kejuangan", UPN "Veteran" Yogyakarta.

Suriadikarta, D. A. (2005). Pengelolaan Lahan Sulfat Masam Untuk Usaha Pertanian. Jurnal Litbang Pertanian, 24(1), 36-45.

Suriadikarta, D. . (2008). Pemanfaatan dan Strategi Pengembangan Lahan Gambut Eks PLG Kalimantan Tengah. Jurnal Sumberdaya Lahan, 2(1).

Tim Sintesis Kebijakan (Balai Besar Penelitian dan Pengembangan Sumberdaya Lahan Pertanian). (2008). Pemanfaatan Dan Konservasi Ekosistem Lahan Rawa Gambut Di Kalimantan. Pengembangan Inovasi Pertanian, 1(2), 149-156. 